Анализ мгновенных параметров сигнала ЭЭГ на основании разложения по эмпирическим модам в применении к паттерну «вспышка-подавление» при анестезии пропофолом

\author{
Г. Соболова ${ }^{1}$, М. С. Фабус², М. Фишер ${ }^{1}$, М. Дробны ${ }^{1 *}$, Б. Дробна-Саниова ${ }^{1 *}$ \\ ${ }^{1}$ Братиславский университет им. Коменского, медицинский факультет Ессениуса в Мартине, \\ Университетская клиника, Клиника анестезиологии и интенсивной медицины, \\ Словацкая Республика, 036 01, г. Мартин, ул. Колларова, д. 2 \\ ${ }^{2}$ Центр интегративной нейровизуализации Веллком, \\ кафедра клинических нейронаук Наффилда, Оксфордский университет, \\ Великобритания, Оксфорд OX3 9DU, Больница Джона Рэдклиффа, Западное крыло, уровень 6
}

\title{
Instantaneous EEG Signal Analysis Based on Empirical Mode Decomposition Applied to Burst-Suppression In Propofol Anaesthesia
}

\author{
Gabriela Sobolova ${ }^{1}$, Marco S. Fabus ${ }^{2}$, Martin Fischer ${ }^{1}$, \\ Michal Drobny ${ }^{1 *}$, Beata Drobna-Saniova ${ }^{*}$ \\ ${ }^{1}$ Clinic of Anaesthesiology and Intensive Medicine, Jessenius Faculty of Medicine in Martin, Comenius University Bratislava, \\ 2 Kollarova Str., 03601 Martin, Slovak Republic \\ ${ }^{2}$ Wellcome Centre for Integrative Neuroimaging, Nuffield Department of Clinical Neurosciences, University of Oxford, \\ Level 6, West Wing, John Radcliffe Hospital, Oxford OX3 9DU, United Kingdom
}

\begin{abstract}
Для цитирования: Г. Соболова, М. С. Фабус, М. Фишер, М. Дробны, Б. Дробна-Саниова. Анализ мгновенных параметров сигнала ЭЭГ на основании разложения по эмпирическим модам в применении к паттерну «вспышка-подавление» при анестезии пропофолом. Общзая реаниматология. 2021; 17 (5): 65-79. https://doi.org/10.15360/1813-97792021-5-65-79 [На русск. и англ.]

For citation: Gabriela Sobolova, Marco S. Fabus, Martin Fischer, Michal Drobny, Beata Drobna-Saniova. Instantaneous EEG signal analysis based on empirical mode decomposition applied to burst-suppression in propofol anaesthesia. Obshchaya Reanimatologiya = General Reanimatology.2021; 17 (5): 65-79. https://doi.org/10.15360/1813-9779-2021-5-65-79 [In Russ. and Engl.]
\end{abstract}

\section{Резюме}

Электроэнцефалограмма (ЭЭГ) представляет собой регистрацию нестационарного и нелинейного электрофизиологического сигнала, возникающего в результате синхронного возбуждения нейронов в таламокортикальных структурах мозга. Из-за сложности организации физиологических структур мозга и его ритмических колебаний при анализе ЭЭГ часто используются методы спектрального анализа.

Цель. Повысить качество клинического мониторинга нейрофизиологических сигналов и получить более глубокие представления об основных принципах функциональных механизмов головного мозга во время анестезии.

Материал и методы. В данной работе использовали разложение по эмпирическим модам (РЭМ) новый метод спектрального анализа, особенно подходящий для нестационарных и нелинейных сигналов. РЭМ и соответствующее преобразование Гильберта-Хуанга (англ. ННТ) разлагают сигнал на составляющие внутренние модовые функции (ВМФ). В данном исследовании применили РЭМ для анализа паттерна «вспышка-подавление» (ПВП) ЭЭГ человека во время индукции общей анестезии $(\mathrm{OA})$ пропофолом. ПВП - это состояние, характеризующееся циклическими изменениями между выраженным подавлением активности мозга и гиперактивными всплесками с переменной продолжительностью, амплитудой и формой волны. ПВП возникает после индукции глубокой общей анестезии, после внутривенного болюсного введения препарата для общей анестезии. В данной статье рассматривается динамика ПВП с помощью отношения «вспышка-подавление» (ОВП).

Результаты. При сравнении связи между ЭЭГ и ОВП внутренних колебаний (англ. IMF, внутренние модовые функции) показали, что ОВП зависит в основном от альфа-активности. Отметили разную скорость возвращения к исходному уровню ОВП для различных спектральных компонентов (IMF 1-4) после исчезновения ПВП на ЭЭГ, что свидетельствует о том, что ПВП может по-разному нарушать функционирование нейронных генераторов низкочастотных осцилляций ЭЭГ и таламокортикальную функциональную связь.

Адрес для корреспонденции:

*Михаил Дробны/E-mail: drobny@unm.sk

*Беата Дробна-Саниова/E-mail: beata.saniova@uniba.sk
Correspondence to:

*Michal Drobny/E-mail: drobny@unm.sk

*Beata Drobna-Saniova/E-mail: beata.saniova@uniba.sk 
Заключение. Изучение ПВП с помощью РЭМ представляет собой новую форму анализа ЭЭГ, способную прояснить нейрофизиологические механизмы данного феномена и его влияние на послеоперационный прогноз состояния пациента.

Ключевые слова: ЭЭГ; электроэниефалография; разложение по эмпирическим модам; ННТ; преобразование Гильберта-Хуанга; паттерн «вспышка-подавление»; внутренние модовые функции; пропофол

Конфликт интересов. Авторы заявляют об отсутствии конфликта интересов.

\section{Summary}

The human electroencephalogram (EEG) constitutes a nonstationary, nonlinear electrophysiological signal resulting from synchronous firing of neurons in thalamocortical structures of the brain. Due to the complexity of the brain's physiological structures and its rhythmic oscillations, analysis of EEG often utilises spectral analysis methods.

Aim: to improve clinical monitoring of neurophysiological signals and to further explain basic principles of functional mechanisms in the brain during anaesthesia.

Material and methods. In this paper we used Empirical Mode decomposition (EMD), a novel spectral analysis method especially suited for nonstationary and nonlinear signals. EMD and the related Hilbert-Huang Transform (HHT) decompose signal into constituent Intrinsic Mode Functions (IMFs). In this study we applied EMD to analyse burst-suppression (BS) in the human EEG during induction of general anaesthesia (GA) with propofol. BS is a state characterised by cyclic changes between significant depression of brain activity and hyper-active bursts with variable duration, amplitude, and waveform shape. BS arises after induction into deep general anaesthesia after an intravenous bolus of general anaesthetics. Here we studied the behaviour of BS using the burst-suppression ratio (BSR).

Results. Comparing correlations between EEG and IMF BSRs, we determined BSR was driven mainly by alpha activity. BSRs for different spectral components (IMFs 1-4) showed differing rates of return to baseline after the end of BS in EEG, indicating BS might differentially impair neural generators of low-frequency EEG oscillations and thalamocortical functional connectivity.

Conclusion. Studying BS using EMD represents a novel form of analysis with the potential to elucidate neurophysiological mechanisms of this state and its impact on post-operative patient prognosis.

Keywords: EEG; EMD; HHT; Burst-Suppression; Intrinsic Mode Functions; Propofol

Conflicts of interest. The authors declare no conflicts of interest.

DOI:10.15360/1813-9779-2021-5-65-79

\section{Введение}

Несмотря на широкое повседневное использование общей анестезии (ОА) в практике, наше понимание нейрофизиологических особенностей ее механизмов все еще остается неполным [1]. Одним из перспективных источников информации об этом состоянии является электроэнцефалограмма (ЭЭГ) и ее обработанный анализ. Общее поведение сигнала ЭЭГ во время ОА можно описать как замедление сигнала в сторону преобладания низкочастотных (<4 Гц) колебаний с появлением глобальных медленных волн со всей поверхности головы [2-4].

Пропофол - наиболее часто используемый общий анестетик, применяемый для индукции ОА. Во время болюсной индукции ОА пропофолом клинически часто достигается транзиторное состояние очень глубокой анестезии, которое проявляется в виде быстрого замедления ритмов ЭЭГ с последующим относительно быстрым наступлением фармакологически индуцированного паттерна «вспышкаподавление» (ПВП), длящегося несколько

\section{Introduction}

Despite the everyday use of general anaesthesia (GA) in the clinic, our understanding of the neurophysiological details of anaesthetic mechanisms still remains incomplete [1]. One of the promising sources of information about this state is the electroencephalogram (EEG) and its processed analysis. The generic behaviour of EEG signal during GA can be described as a slowing of the signal towards low-frequency $(<4 \mathrm{~Hz})$ oscillations with appearance of global slow waves across the scalp [2-4 ].

Propofol is the most commonly used general anaesthetic, included during the induction of GA. During a propofol bolus GA induction it is clinically common to reach a transient state of very deep anaesthesia, which manifests as a rapid slowing of EEG rhythms followed by a relatively fast onset of a pharmacologically-induced burst-suppression (BS) lasting for several minutes. This state is characterised by cyclical transitions between significant depression of brain activity (suppression) and bursts of increased activity with variable amplitude, duration, and waveform shape. It is standard practise to consider a recording as undergoing BS if 
минут. Этот феномен характеризуется циклическими переходами между выраженным угнетением активности мозга (подавлением) и всплесками повышенной активности (вспышка) с переменной амплитудой, продолжительностью и формой волны. Согласно стандартной практике, феномен ПВП диагностируют, если более $50 \%$ записи потенциалов на ЭЭГ подавлено отдельными всплесками длительностью 0,5-30 с. При дальнейшем углублении ОА наблюдается удлинение фаз подавления с уменьшением частоты всплесков, что в конечном итоге приводит к изоэлектрической ЭЭГ, так называемому «изоэлектрическому молчанию» [5]. В клинической практике, однако, нередко после нескольких минут ПВП наблюдается вымывание эффектов пропофола и возвращение к глубокой ОА с медленными ритмами ЭЭГ, необходимыми для проведения операции. В этом случае ПВП отражает необходимость быстрой и достаточно глубокой индукции ОА для обеспечения безопасности дыхательных путей при интубации трахеи. Количество вводимого анестетика подбирается строго индивидуально, исходя из пола, возраста, роста и веса пациента, с учетом сопутствующих заболеваний и текущего клинического состояния - хотя чаще всего без проверки активности самого мозга [6]. Чистые опиоиды не способны вызывать ПВП даже в высоких дозах, лишь в сочетании с другими веществами они оказывают аддитивный эффект, вызывая ОА. Они способствуют общему замедлению ритмов ЭЭГ при ОА и оказывают дозозависимый эффект на ПВП. Обычно используемые низкие анальгетические дозы опиоидов во время индукции ОА оказывают слабое влияние на ритмы ЭЭГ и появление ПВП [7]. Появление ПВП на поддерживающем этапе ОА, т.е. от начала до конца хирургического вмешательства, сопровождается ухудшением послеоперационного прогноза и большей частотой развития делирия, хотя подробности этой взаимосвязи и ее механизмы остаются неясными. До сих пор не было доказано, что появление обычного кратковременного ПВП во время индукции ОА оказывает патологическое влияние на пациентов, а роль интраоперационного ПВП требует активного изучения [8-11].

Преобразование Гильберта-Хуанга (англ. ННТ) - это новый метод спектрального разложения для обработки и анализа нелинейных и нестационарных сигналов, к которым относится и ЭЭГ. Оно способно объяснить суть процессов, генерирующих электрическую активность мозга, лучше, чем традиционные методы, основанные на преобразовании Фурье [12-14]. ННТ состоит из двух частей, разложения по эмпирическим модам (РЭМ, предмет нашего исследо- more than $50 \%$ of it is suppressed with individual bursts lasting 0.5-30s. In case of further deepening of GA, we observe lengthening of suppression phases with a lowered frequency of bursts, eventually leading to isoelectric EEG, so called «isoelectric silence» [5]. In clinical practice, it is however common after a few minutes of BS to observe a washout of propofol effects and a return to deep GA with slow EEG rhythms required for performing surgery. In this case, BS mirrors the need for a rapid and sufficiently deep induction of GA for ensuring safety of the respiratory tract by intubation. The amount of anaesthetic delivered is strictly chosen individually based on patient's sex, age, height, and weight, considering related diseased and the patient's current clinical state - though most often without checking brain activity itself [6]. Pure opioids are unable to induce BS even at high doses, only together with other substances do they have an additive effect in inducing GA. They contribute to general slowing of EEG rhythms in GA, and have a dose-dependent effect on BS. Commonly used low analgesic doses of opioids during GA induction have a low impact on EEG rhythms and appearance of BS [7]. The appearance of BS during maintenance of GA, i.e. from the start to the end of the surgical intervention, has been linked to worse postoperative prognosis and higher incidence of delirium, though details of this relationship and its mechanisms remain unresolved. Common shortterm BS during induction of GA has so far not been shown to have a pathological influence on patience, and its relationship to intraoperative BS remains an active field of study [8-11].

The Hilbert-Huang Transform (HHT) is a novel spectral decomposition method for processing and analysis of nonlinear and nonstationary signals such as the EEG. It has the potential to explicate generators of brain activity further than traditional methods based on the Fourier Transform [12-14]. HHT consists of two parts, Empirical Mode Decomposition (EMD, the subject of our study) and the Hilbert Spectrum, a distribution of energy in the time-frequency domain based on the Hilbert Transform. EMD decomposes analysed signal into Intrinsic Mode Functions (IMFs), which are based on local properties of the signal. This allows for a physically meaningful definition of instantaneous frequency and removes the need for using harmonic functions to represent nonlinear and nonstationary signals unlike the Short-time Fourier Transform.

Empirical Mode Decomposition. Empirical Mode Decomposition (EMD) is a novel method for decomposing nonstationary and nonlinear signals (e. g. EEG) into Intrinsic Mode Functions [12]. It has been described elsewhere, but in short it is a datadriven method that resolves different spectral components based on extrema detection [15]. 
вания) и спектра Гильберта, распределения энергии во временно-частотной области на основе преобразования Гильберта.

ЭМР разлагает анализируемый сигнал на внутренние колебания, или модовые функции (англ. IMF), которые основаны на локальных свойствах сигнала. Это позволяет дать физически значимое определение мгновенной частоты и устраняет необходимость использования гармонических функций для представления нелинейных и нестационарных сигналов в отличие от кратковременного преобразования Фурье.

Разложение по эмпирическим модам. Разложение по эмпирическим модам (РЭМ, англ. Empirical Mode Decomposition, EMD) это новый метод разложения нестационарных и нелинейных сигналов (например, ЭЭГ) на внутренние модовые функции [12]. Он подробнее описан в других источниках, но вкратце характеризуется как метод, основанный на обработке данных, позволяющий разложить различные спектральные компоненты в соответствии с обнаруженными экстремальными значениями [15].

Оригинальный алгоритм РЭМ часто страдает от так называемой проблемы смешивания мод при применении к реальным данным [16, 17]. Эта проблема возникает при наличии переходных колебаний, когда распределение локальных экстремумов меняется в разных частях сигнала. Смешение мод усложняет интерпретацию и анализ разложения внутренних колебаний, поэтому были предложены усовершенствования оригинального алгоритма РЭМ. К ним относятся ансамблевый РЭМ (АРЭМ) и маскирующий РЭМ (МРЭМ). Эти методы основаны на введении дополнительного сигнала в исходную запись перед процессом просеивания (белый шум для АРЭМ, заранее определенные синусоиды в МРЭМ). При этом происходит нормализация распределения частот экстремумов по сигналу, что приводит к уменьшению смешивания мод.

\section{Материал и методы}

В данном исследовании провели регистрацию ЭЭГ у 39 пациентов, находящихся под наркозом, и применили разложение по эмпирическим модам (РЭМ) к записям 30 пациентов с ПВП (15 женщин и 15 мужчин, средний возраст 62 года). Данные испытуемых были записаны в рамках исследования APVV («Уровень сознания и его изменения во время анестезии в торакальной хирургии») (APVV-0223-12) в рамках междисциплинарного исследовательского проекта Агентства по продвижению исследований и разработок с участием клиники анестезиологии и интенсивной медицины, и клиники торакальной хирургии университетской больницы Мартина, и медицинским факультетом Есениуса Университета имени Коменского в Братиславе. Испытуемым был
The original EMD algorithm often suffers from the so-called mode mixing problem when applied to real data $[16,17]$. This problem occurs in presence of transient oscillations, where the distribution of local extrema varies in different parts of the signal. Mode mixing complicates interpretation and analysis of the IMF decomposition, hence improvements to the original EMD algorithm have been proposed. These include ensemble EMD (EEMD) and masking EMD (MEMD). These methods are based on injecting an additional signal into the original recording before the sifting process (white noise for EEMD, pre-defined sinusoids in MEMD). This normalises the distribution of extrema rates across the signal, which leads to lowered mode mixing.

\section{Materials and Methods}

In this study, we measured EEG in 39 anaesthetised patients and applied Empirical Mode Decomposition (EMD) on recordings from 30 patients showing burstsuppression (15 women and 15 men, average age 62 years). The subjects were recorded as part of the AAPV study - «Level of consciousness and its changes during anaesthesia in thoracic surgery» (APVV-0223-12), as a part of the joint interdisciplinary research project of the Agency for the Advancement of Research and Development between the Clinic of Anaesthesiology and Intensive Medicine and the Clinic Thoracic Surgery of University Hospital Martin and the Jessenius Faculty of Medicine in Comenius University Bratislava. The subjects underwent a spectrum of selective diagnostic and therapeutic thoracic surgeries (e.g. diagnostic biopsy, bilobectomy, dual chamber interventions). As part of the APVV project all surgical interventions shared the use of thoracotomy, i. e. an intervention with an «open chest» with the need for single-sided lung ventilation (One Lung Ventilation - OLV). Given the nature of the surgery, the recorded subjects were under deep general anaesthesia (GA) with a high need for analgesics and muscle relaxants. The administration of GA was exclusively done by a practicing anaesthesiologist and underwent in a standard manner according to local conventions. A specific use and dosing of drugs was chosen by the anaesthesiologist given their clinical abilities and experience, including the current clinical condition of the patient and the course of the operation.

Patients arrived in the operating theatre without pre-surgical morning premedication. Induction of GA began after fitting of the EEG cap. Initially, patients were given intravenous analgesia with a sufentanil bolus (dose: $0.15 \mu \mathrm{g} / \mathrm{kg}$ ). This was followed by an intravenous propofol anaesthetic bolus (dose: $2-2.5 \mathrm{mg} / \mathrm{kg}$ ) together with an intravenous muscle relaxant. After GA induction confirmed by a deep unconsciousness without reactions to a painful stimulus and complete muscle relaxation, orotracheal intubation was performed and the surgical procedure began.

Patients were excluded if they suffered head injuries leading to loss of consciousness, were addicted to alcohol or medication, they were known to have poor or non-standard tolerance of anaesthesia, they had known neurological or psychiatric conditions, or they were currently using 
проведен спектр селективных диагностических и лечебных торакальных вмешательств (например, диагностическая биопсия, двусторонняя лобэктомия, имплантация двухкамерного искусственного водителя ритма).

В рамках проекта APVV при всех хирургических вмешательствах использовалась торакотомия, т. е. вмешательства проводились с «открытой грудной клеткой» при необходимости однолегочной вентиляции (ОЛВ). Учитывая характер операции, исследуемые находились под глубокой общей анестезией (OA) с высокой потребностью в анальгетиках и мышечных релаксантах. Введение в ОА осуществлялось исключительно опытным анестезиологом и проходило стандартным образом в соответствии с местными протоколами. Вопрос применения конкретного препарата и его дозировки решал анестезиолог с учетом своих клинических возможностей и опыта, а также текущего клинического состояния пациента и хода операции.

Пациенты поступали в операционную без предоперационной утренней премедикации. Индукция ОА начиналась после надевания комплекса ЭЭГ-датчиков на голову. Сначала пациенты получали внутривенную аналгезию с помощью болюса суфентанила (в дозе 0,15 мкг/кг). Затем вводился внутривенно болюсно анестетик пропофол (в дозе 2-2,5 мг/кг) вместе с мышечным релаксантом внутривенно. После индукции $\mathrm{OA}$, подтвержденной глубокой утратой сознания без реакции на болевые раздражители и полным расслаблением мышц, выполнялась оротрахеальная интубация и начиналось хирургическое вмешательство.

Пациентов исключали из исследования, если у них были травмы головы, сопровождавшиеся потерей сознания, при наличии алкогольной или лекарственной зависимости, при наличии в анамнезе сведений о плохой или нестандартной переносимости анестезии, при наличии указаний на неврологические или психиатрические заболевания, или при употреблении психотропных препаратов в настоящее время. Во всех случаях пациенты давали письменное согласие на проведение исследования, которое одобрено этическим комитетом в рамках проекта APVV.

Пациентам, подготовленным к операции и давшим письменное согласие, записывали ЭЭГ с помощью программного обеспечения Neuron Spectrum AM (Neurosoft), используемого для записи ЭЭГ и полисомнографии. Перед операцией каждому пациенту надевали комплект электродов (ЭЭГ-шапочка с 19 электродами, расположенными на коже головы в соответствии со стандартизированной системой 10 20 и усредненными нормативами). Конкретный размер шапочки для пациента определяли путем измерения окружности головы с помощью рулетки и использования таблицы размеров производителя. Шапочка ЭЭГ плотно прилегала к голове пациента, а на каждый электрод ЭЭГ помещали проводящий гель для обеспечения подходящего импеданса между электродом и кожей головы. Импеданс электродов во время процедуры не превышал 25 кОм. Необработанные записи состояли из ЭЭГ в широком частотном диапазоне с нижней границей, определяемой медленными дрейфами около 0,5-1 Гц, и верхней границей Найквиста от используемой частоты дискретизации 500 Гц. ЭЭГ непрерывно запи- psychotropic drugs. In all cases patients gave written consent to the study and the research study was approved by an ethics committee as part of the APVV project.

Patients who underwent surgery and gave written consent had their EEG recorded using the Neuron Spectrum AM recording software (Neurosoft), used for recording EEG and polysomnography. Before the operation, each patient was fitted an EEG cap with 19 electrodes placed on the scalp (not intracranially) according to the standardised 10-20 system, referenced to the average montage. The specific cap size for a patient was determined by measuring their head circumference with a tape measure and using the manufacturer's sizing table. EEG cap was tightly fitted to the patient's head and conductive gel was put into each EEG electrode to ensure suitable impedance between the electrode and the scalp. Electrode impedance during the procedure did not exceed $25 \mathrm{k} \Omega$. The raw recording collected consisted of EEG in a wide frequency band with a lower bound determined by slow drifts around $0.5-1 \mathrm{~Hz}$ and an upper Nyquist bound from the sampling frequency of $500 \mathrm{~Hz}$ used. EEG was continuously recorded during the operation including the induction to GA and surgery. EEG recording was stopped after the end of surgery and after emergence from GA. The EEG cap was removed just after extubation when the patient was spontaneously breathing and responsive to verbal stimulus. Further markers were inserted into the EEG recording to note intravenous medications administered, their dose, and time of administration.

Pre-processing and analysis of EEG data. For archiving, viewing, and filtering raw EEG data we used the Neuron Spectrum.NET software (Neurosoft), which includes tools for EEG spectral analysis. Recorded EEG was visually checked, and artefacts were manually removed after consulting with an experienced neurologist. For EMD analysis we re-referenced the data to $\mathrm{Cz}$ and used the Fz electrode for further analysis. This way large artefacts affecting most of the scalp due to the surgical environment were reduced. EEG data was further filtered to remove line noise, muscle artefacts, ECG artefacts, and breathing artefacts. Further analysis was done in a custom script using Python 3.6. Data was first filtered by a Finite Impulse Response (FIR) bandpass filter in the 0.5$35 \mathrm{~Hz}$ band using the open-source Python MNE package [21]. The Hamming FIR window was used to suppress edge effects and increase computational stability. Afterwards data were resampled to $100 \mathrm{~Hz}$ and EMD analysis was done with the Python emd module $[22,23]$.

In order to reduce mode mixing, masked EMD with masking frequencies $14-7-2.5-0.5-0.2 \mathrm{~Hz}$ was performed. Masking frequencies were chosen by an experienced EMD researcher to best represent the dominant alpha-delta nature of brain activity after administering propofol. It is important to note that whilst these masks reduce mode mixing, they do not impose tight bandwidth limits on spectral components unlike standard Fourier analysis. Maximum number of IMFs was set to $N=5$ and the first four (IMF1-IMF4) were used for further analysis. Burst-suppression pattern was quantified with the Burst-Suppression Ratio [24, 25]. EEG was defined as suppressed if its absolute value was under $5 \mu \mathrm{V}$ for longer than $0.5 \mathrm{~s}$. To enable direct comparison between BSR values obtained from IMFs and the EEG, a section of the IMF was considered suppressed if its amplitude was under $40 \%$ of the standard deviation of that IMF for at 
сывали во время вмешательства, в том числе - в течение периода индукции ОА и самой операции. Запись ЭЭГ прекращали после окончания операции и выхода из ОА. Шапочку ЭЭГ снимали сразу после экстубации трахеи при спонтанном дыхании и реагировании на вербальные стимулы. В запись ЭЭГ вносили дополнительные маркеры моментов внутривенного введения лекарств с указанием препарата, дозы и времени введения.

Предварительная обработка и анализ данных ЭЭГ. Для архивирования, просмотра и фильтрации необработанных данных ЭЭГ использовали программу Neuron Spectrum.NET (Neurosoft), которая включает инструменты для спектрального анализа ЭЭГ. Запись ЭЭГ проверяли визуально, а артефакты удаляли вручную после консультации с опытным неврологом. Для анализа РЭМ данные повторно «привязывали» $\mathrm{Cz}$, а для дальнейшего анализа использовали электрод Fz. Таким образом были уменьшены существенные артефакты, полученные с большей части кожи головы в условиях хирургического вмешательства. Данные ЭЭГ дополнительно отфильтровали для удаления линейного шума, мышечных артефактов, артефактов ЭКГ и артефактов дыхания. Дальнейший анализ проводили в пользовательском сценарии с использованием Python 3.6. Сначала данные отфильтровали полосовым фильтром с конечной импульсной характеристикой (FIR) в диапазоне 0,5-35 Гц, с использованием пакета MNE из Python и открытым исходным кодом [21]. Для подавления краевых эффектов и повышения стабильности вычислений использовали FIR-окно Хэмминга. Затем данные передискретизировали до 100 Гц, и провели РЭМ-анализ с помощью модуля Python emd [22, 23].

Для того чтобы уменьшить смешение режимов, проводили маскированное РЭМ с маскирующими частотами 14-7-2,5-0,5-0,2 Гц. Маскирующие частоты были выбраны опытным специалистом по РЭМ для оптимального представления доминирующей альфа-дельта природы активности мозга после введения пропофола. Важно отметить, что хотя эти маски уменьшают смешение мод, они не накладывают жестких ограничений на полосу пропускания спектральных компонентов в отличие от стандартного Фурье-анализа. Максимальное количество внутренних колебаний (IMF) установили на $n=5$, и для дальнейшего анализа использовали первые четыре (IMF1-IMF4). Количественную оценку ПВП проводили с помощью определения отношения «вспышка-подавление» (ОВП) [24, 25]. ЭЭГ определяли как подавленную, если ее абсолютное значение было меньше 5 мкВ в течение более 0,5 с. Для прямого сравнения значений ОВП, полученных на основе анализа внутренних колебаний и ЭЭГ, «подавленным» считали участок внутренних колебаний, амплитуда которого составляла менее $40 \%$ от стандартного отклонения этого колебания в течение не менее 0,5 секунды. Затем ОВП рассчитывали для ЭЭГ и отдельных внутренних колебаний как отношение продолжительности подавленной части сегмента к продолжительности всего исследуемого сегмента. ОВП рассчитывали для каждой минуты из первых 15 минут индукции ОА (время перекрытия между сегментами составило $10 \mathrm{c}$ ). least $0.5 \mathrm{~s}$. BSR was then calculated for the EEG and individual IMFs as the ratio of the duration of the suppressed part of a segment to the whole segment studied. BSR was calculated for each minute of the first 15 minutes of GA induction (10s overlap between segments).

\section{Results and Discussion}

EEG recordings from 30 anaesthetised patients ( 15 women, 15 men) showing burst-suppression during propofol induction were analysed and visualised using the Python emd module. Examples of these results are displayed in Fig. 1, 2 and Fig. 4.

Figure 1 displays an example decomposition of EEG using masked EMD. We observed four nontrivial IMFs (IMF1 - IMF4). These represented well-known physiological rhythms despite not having pre-defined frequency bands in the analysis. They matched with alpha $(\sim 10 \mathrm{~Hz}, \mathrm{IMF} 1)$, high delta $(\sim 4 \mathrm{~Hz}$, IMF2), low delta $(\sim 2 \mathrm{~Hz}$, IMF3), and slow oscillations ( $<1.5 \mathrm{~Hz}$, IMF4), with IMF5 representing residual low-frequency noise. The signal was represented with a small number of components unlike the Fourier transform, where the output is a potentially infinite number of harmonic components.

Figure 2 shows example EMD results from a representative induction segment including a burst-suppression pattern. Typical sample of BS is illustrated in EEG Fig. 3.

Again we observed a data-driven decomposition of the EEG signal into four components. Each component in succession captured slower EEG activity and a physiologically relevant part of the spectrum. Burst-suppression was seen to affect all spectral components. To analyse its effect further, we computed the burst-suppression ratio (BSR) to quantify suppression of the signal.

Figure 4 shows the BSR over time for $15 \mathrm{~min}$ utes from a bolus propofol GA induction. BSR was calculated for each minute for both the full EEG recording and individual spectral components captured by IMFs. The general trace captures the classical effect of propofol on the EEG and show propofol's strong effect on brain activity and the EEG with an initial rise and saturation of low-frequency activity and later the appearance of burst-suppression. At the start of the induction, low frequencies have a low power and hence appear suppressed (high BSR for IMF2-IMF4) with alpha activity being dominant (IMF1 BSR lowest). After applying the propofol bolus delta and slow-wave activity gradually increase, driving BSR to low values around $t=300 \mathrm{~s}$. As the effect-site concentration of propofol rapidly increases, burst-suppression starts appearing in the recording around $t=400 \mathrm{~s}$ and all spectral components become suppressed. BSR from IMF1 (alpha activity) had the highest Pearson correlation with BSR from the filtered EEG, which shows BSR is mainly driven by the alpha spectral component. As 


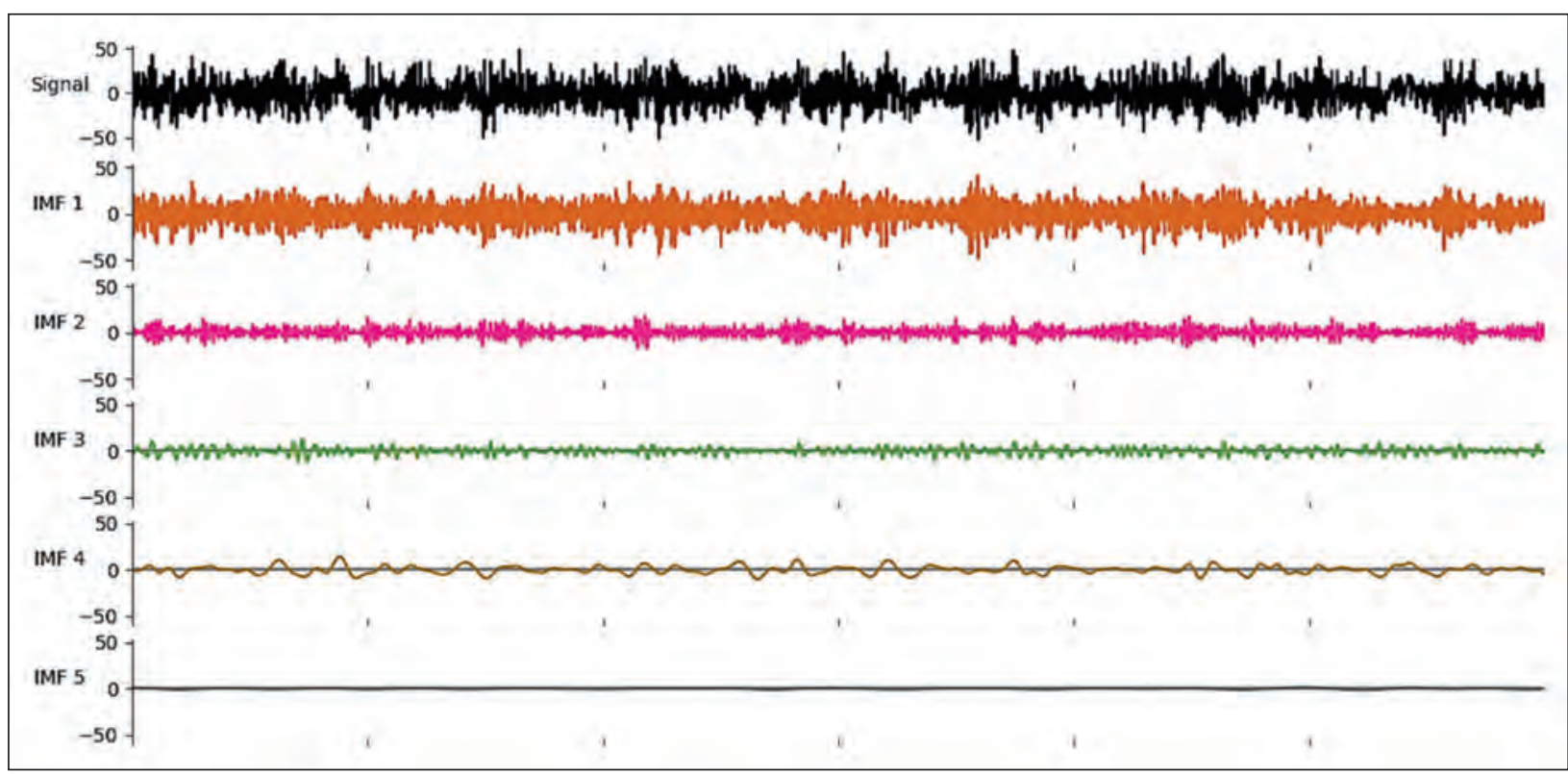

Рис. 1. Пример внутренних колебаний в течение 60 с, полученных с помощью РЭМ на ЭЭГ пациента в состоянии легкой анестезии.

Fig. 1. Example 60s of IMFs obtained from EMD for light anaesthesia EEG.

Note. EMD decomposed the signal into physiologically relevant alpha and delta rhythms (IMF1-IMF4) and low-frequency noise (IMF5).

Примечание. С помощью РЭМ сигнал разложен на физиологически значимые альфа- и дельта-ритмы (IMF1-IMF4) и низкочастотный шум (IMF5).

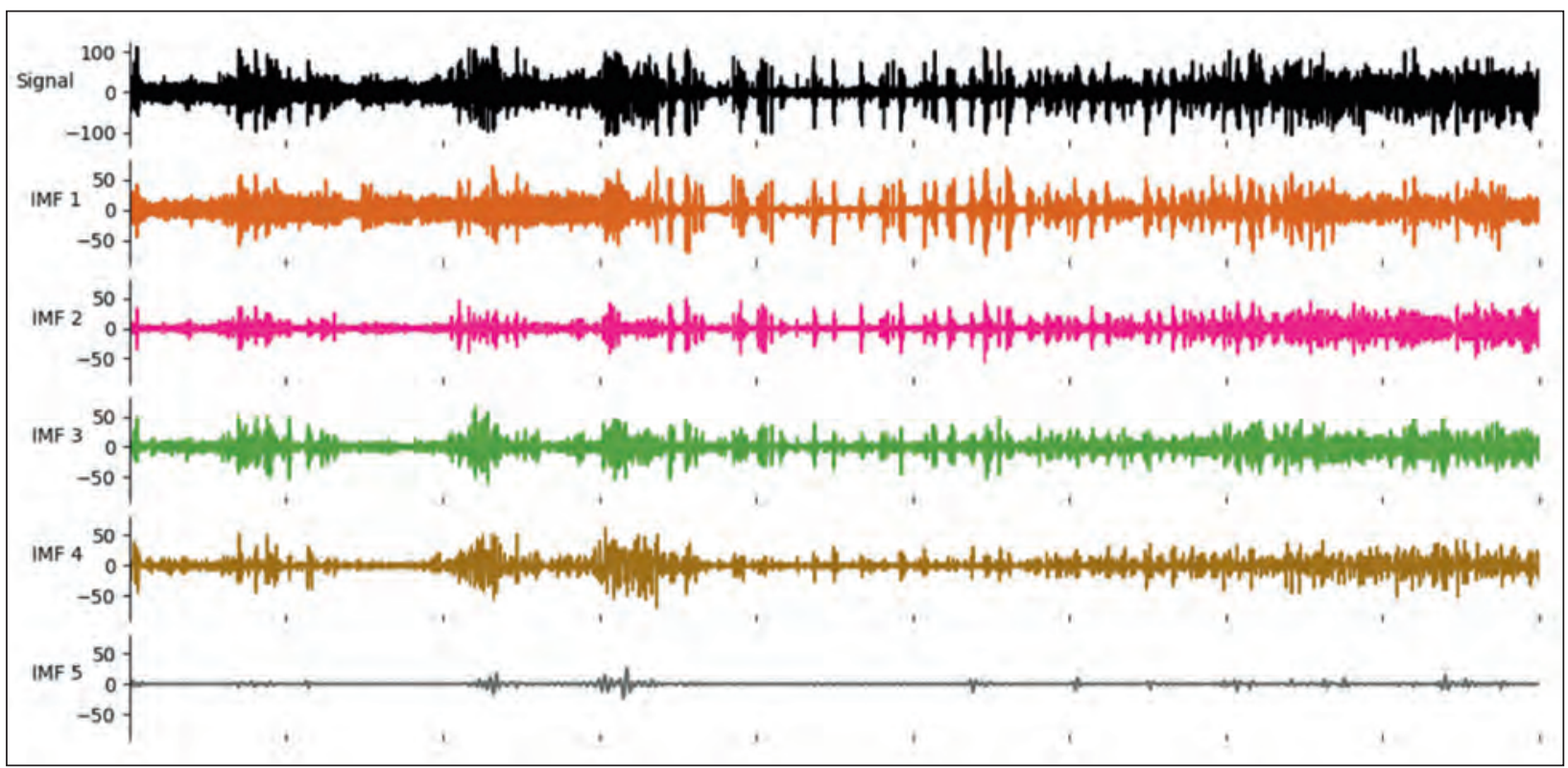

Рис. 2. Пример первых 15 минут внутренних колебаний (IMF), полученных с помощью РЭМ.

Fig. 2. Example first 15 min of IMFs obtained from EMD.

Note. The Burst-Suppression pattern visible in the middle part of the recording.

Примечание. Внимание привлекает ПВП, видимый в средней части записи.

\section{Результаты и обсуждение}

Записи ЭЭГ 30 анестезированных пациентов (15 женщин, 15 мужчин), демонстрирующие ПВП во время индукции пропофолом, анализировали и визуализировали с помощью модуля Python emd. Примеры полученных результатов представили на рис. 1, 2 и 4. suppression of alpha activity seemed to be most relevant for predicting overall EEG burst-suppression, we may term burst-suppression as «alpha burstsuppression» when studied with the EEG BSR. Interestingly, after the end of burst-suppression in the EEG (BSR returns to zero), different spectral components had a differential rate of return to low values. Slow-wave activity (IMF4) stopped being sup- 


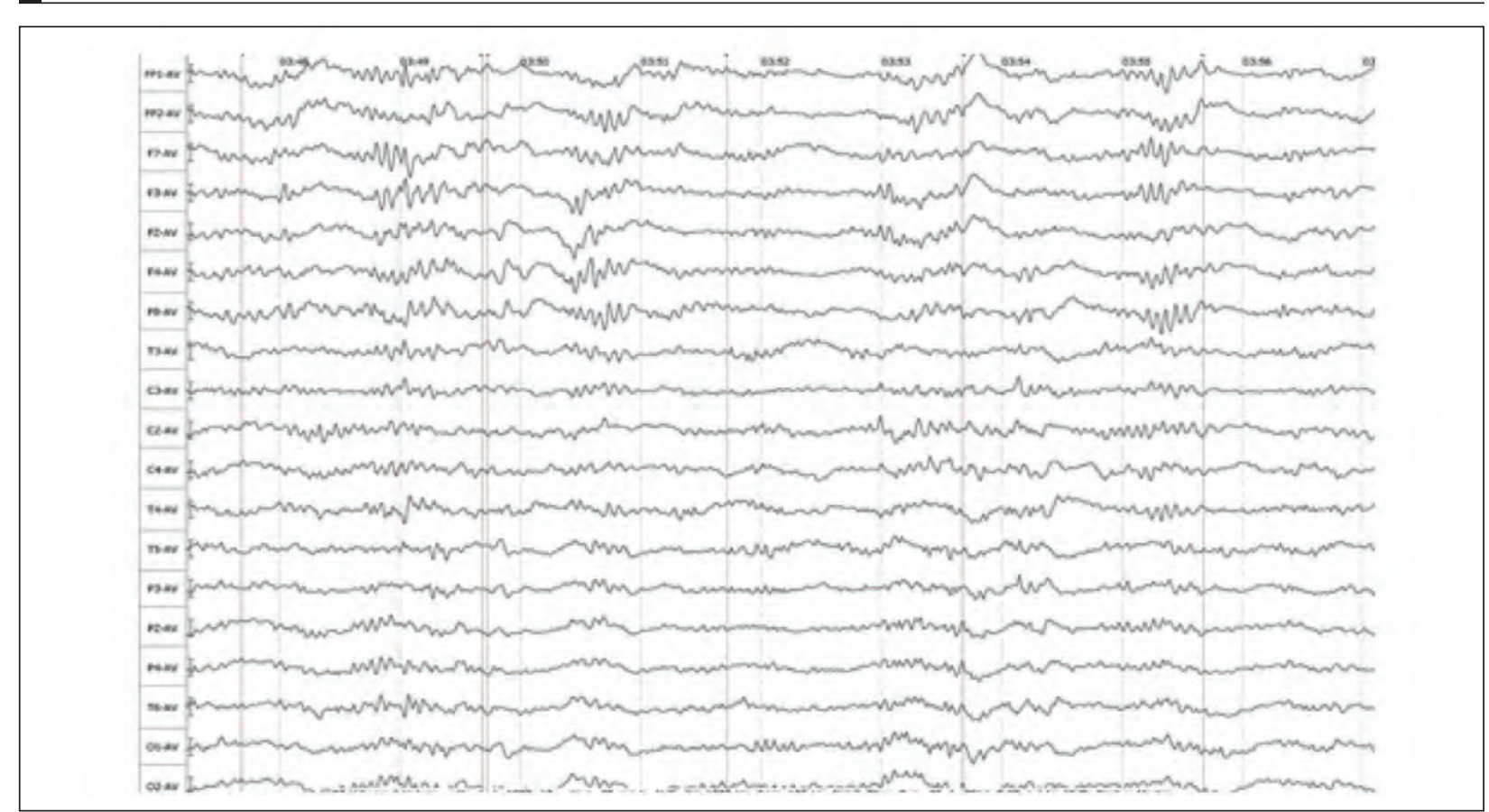

Рис. 3. Пример 10-секундной записи ЭЭГ 55-летнего пациента, демонстрирующей ПВП после применения пропофола. Fig. 3. Example 10 seconds from an EEG recording of a 55 year old patient showing burst-suppression after application of propofol.

На рис. 1 показали пример разложения ЭЭГ с помощью маскированного РЭМ. Наблюдали четыре нетривиальные внутренние модовые функции (IMF1 - IMF4). Они представляли хорошо известные физиологические ритмы, несмотря на отсутствие заранее определенных частотных полос в анализе и соответствовали альфа ( 10 Гц, IMF1), высокой дельта ( 4 Гц, IMF2), низкой дельта ( 2 Гц, IMF3) и медленным колебаниям (<1,5 Гц, IMF4), a IMF5 соответствовала остаточному низкочастотному шуму. Сигнал был представлен небольшим числом компонентов, в отличие от преобразования Фурье, где на выходе получается потенциально бесконечное число гармонических компонентов.

На рис. 2 показан пример результатов РЭМ с репрезентативного сегмента записи периода индукции анестезии, включающего ПВП. Типичный пример ПВП показан на ЭЭГ на рис. 3.

И снова наблюдали разложение сигнала ЭЭГ на четыре компонента, в основе которого лежала обработка данных. Каждый компонент последовательно захватывал более медленную активность ЭЭГ и физиологически значимую часть спектра. Было видно, что подавление вспышек затрагивает все спектральные компоненты. Для количественной оценки подавления сигнала вычислили отношение «вспышка-подавление» (ОВП).

На рис. 4 показали изменение ОВП во времени в течение 15 минут после болюсной индукции ОА пропофолом. ОВП рассчитывали для каждой минуты как для полной записи pressed only after higher spectral components: first alpha, then high delta, low delta, and slow activity last. This means that the burst-suppression state has a substantial effect on generators of low-frequency EEG oscillations and may impact different thalamocortical functional pathways differently with slow oscillations returning into the brain only after those with higher frequencies.

Figure 5 shows the Wavelet transform (WT) in a $3 \mathrm{D}$ view for the $\mathrm{Fz}-\mathrm{Cz}$ electrode and the corresponding spectrogram for comparison with EMD results. The graph clearly shows high presence of low-frequency power (red colour) including delta and theta oscillations. This shows patients were deeply sedated during the induction into GA and were in a state of deep anaesthesia, as seen in the EMD results. After reaching maximal effect-site concentration of administered propofol the Wavelet transform showed that higher propofol doses led to higher amplitudes for low-frequency characteristics of the spectrum. This confirms that higher doses of anaesthetics lead to rapid decreases in the cortical EEG complexity and increases of the anaesthetic effects [26]. Spatial distribution of spectral activity including delta and theta was investigated using topographical maps produced by 2D Brain Mapping (BM). We saw the global increase in presence of slow delta activity (red) and the absence of rapidly changing beta and gamma rhythms in GA, once again showing the anaesthesiologic effect of administered propofol (fig. 6).

Burst-suppression during general anaesthesia. The goal of an anaesthesiologist is to ap- 


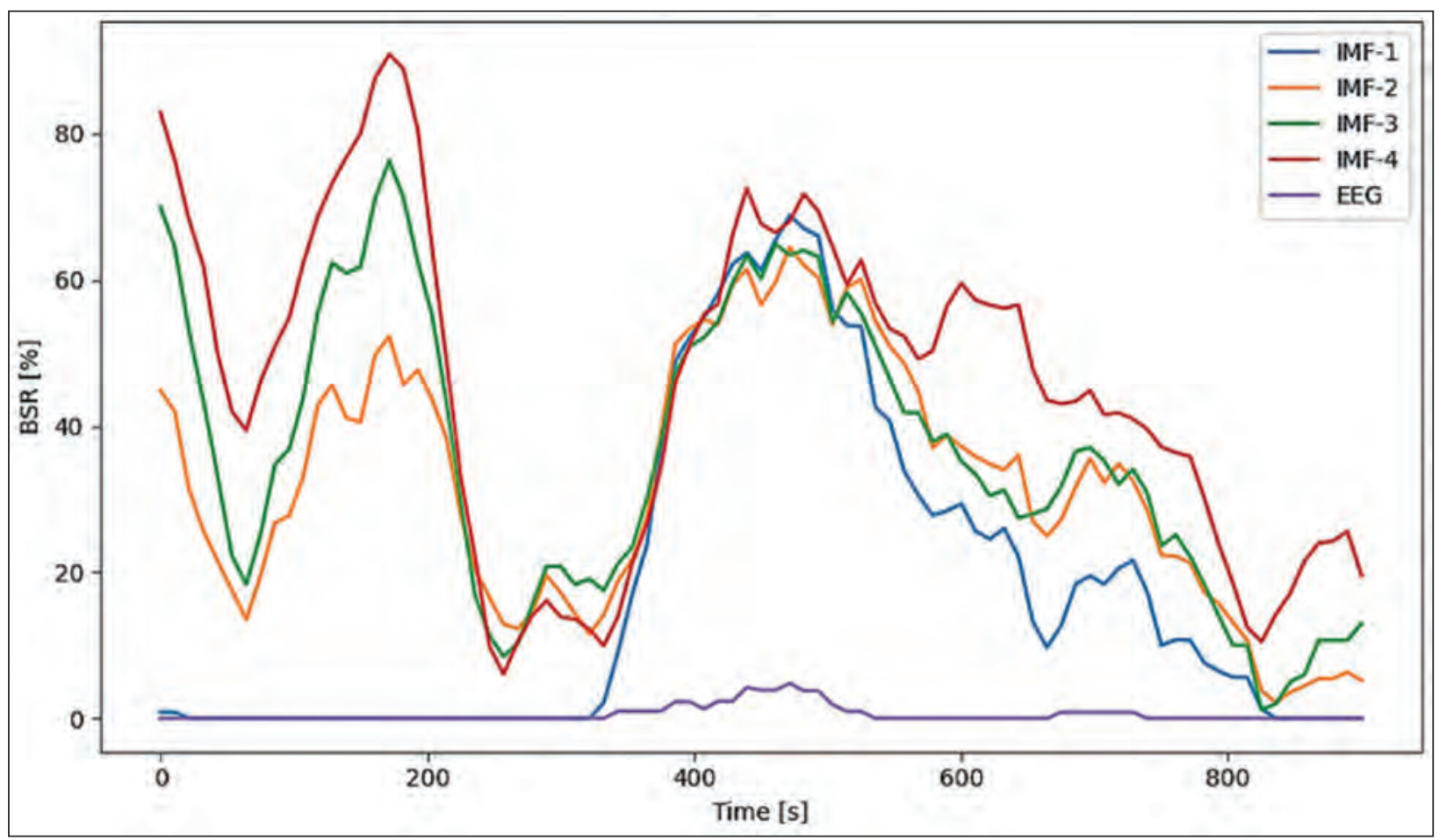

Рис. 4. Пример оценки отношения «вспышка-подавление» в динамике при индукции ОА пропофолом.

Fig.4. Example Burst-Suppression Ratio (BSR) trace over time for induction of GA with propofol.

Note. Low-frequency oscillations show prolonged suppression after burst-suppression in the EEG (purple trace, around 420s), most prominent for slow oscillations (IMF4, red).

Примечание. Наблюдается длительное подавление низкочастотных колебаний после подавления вспышки на ЭЭГ (фиолетовый след, около 420 c), наиболее заметное для медленных колебаний (IMF4, красный).

ЭЭГ, так и для отдельных спектральных компонентов, захваченных внутренними колебаниями. На общей ЭЭГ отражено классическое влияние пропофола на ЭЭГ и активность мозга в виде первоначального подъема и насыщения низкочастотной активности, а затем появления ПВП. В начале индукции низкие частоты имеют низкую мощность и поэтому кажутся подавленными (высокое ОВП у IMF2-IMF4) с преобладанием альфа-активности (OBП IMF1 самое низкое). После введения болюса пропофола дельта- и медленноволновая активность постепенно увеличиваются, доводя ОВП до низких значений в период времени $t=300$ с. По мере быстрого увеличения концентрации пропофола на записи около $t=400$ с начинает появляться ПВП, и все спектральные компоненты подавляются. ОВП у IMF1 (альфа-активность) наиболее выраженно коррелировало (по данным корреляции Пирсона) с ОВП от фильтрованной ЭЭГ, что говорит о том, что ОВП в основном определяется альфа-спектральным компонентом. Поскольку подавление альфа-активности оказалось наиболее значимым для глобального предсказания ПВП на ЭЭГ, можно назвать феномен подавления вспышек «подавлением альфа-вспышек» на основании изучения ОВП на ЭЭГ. Интересно, что после исчезновения ПВП на ЭЭГ (ОВП воз- propriately diminish a patient's consciousness and their awareness of pain in combination with appropriate muscle relaxation during surgery. This enables the surgical procedure to happen in the first place, whilst keeping haemodynamic stability maximises the patient's chances for a good intraoperative procedure and its resulting clinical outcomes. Researching burst-suppression (BS) is a substantial part of this endeavour, as neuronal mechanisms of BS are only partly understood and electrophysiological changes during the induction of GA can help us understand the effect of general anaesthetics on brain structures and illuminate mechanisms of consciousness changes during GA. An important role in these phenomena is played by thalamocortical communication and functional connectivity between parts of cortex, which manifest amongst other things as alpha oscillations on the scalp [11, $27,28]$. In our analysis, the IMF representing alpha activity was most predictive of overall EEG BSR, which may thus reflect changes in thalamocortical communication during burst-suppression. A promising clinical marker of the appropriate depth of anaesthesia is saturation of slow-wave activity (SWAS. However, it is not known how slow-wave activity behaves after the occurrence of burst-suppression. Our results indicate that low-frequency activity (delta and slow 
вращается к нулю) скорость восстановления низких значений различных спектральных компонентов была различной. Медленно-волновая активность (IMF4) перестала подавляться только после более высоких спектральных компонентов: сначала альфа, затем высокая дельта, низкая дельта, и медленная активность последней. Это означает, что ПВП оказывает существенное влияние на генераторы низкочастотных колебаний ЭЭГ и может по-разному воздействовать на различные таламокортикальные функциональные пути, при этом медленные колебания вновь возникают в мозге только после более высокочастотных.

На рис. 5 показали вейвлет-преобразование в трехмерном виде для электродов Fz-Cz и соответствующая спектрограмма для сравнения с результатами РЭМ. На графике четко видно высокое присутствие низкочастотной активности (красный цвет), включая дельта- и тета-осцилляции. Это свидетельствует о том, что пациенты находились в глубокой седации во время индукции ОА, что соответствует состоянию глубокой анестезии, как видно из результатов РЭМ. После достижения максимальной концентрации введенного пропофола вейвлет-преобразование показало, что более высокие дозы пропофола привели к более высоким амплитудам для низкочастотных характеристик спектра. Данный факт свидетельствует о том, что более высокие дозы анестетиков приводят к быстрому упрощению корковой ЭЭГ и усилению эффекта анестезии [26]. Пространственное распределение спектральной активности, включая дельта и тета-волны, исследовали с помощью топографических карт, созданных с помощью 2D Brain Mapping. Визуализировали глобальное увеличение присутствия медленной дельта-активности (красный цвет) и отсутствие быстро меняющихся бета- и гамма-ритмов во время ОА, что еще раз говорит об анестезиологическом эффекте введенного пропофола (рис. 6).

Феномен «вспышка-подавление» во время общей анестезии. Целью анестезиолога является адекватная утрата сознания пациента и ощущения боли в сочетании с соответствующей мышечной релаксацией во время операции. При этом становится возможным проведение хирургического вмешательства, а поддержание гемодинамической стабильности дает высокие шансы на отсутствие интраоперационных осложнений и получение оптимального результата операции. Исследование ПВП является существенной частью этих усилий, поскольку нейронные механизмы ПВП расшифрованы не до конца, а познание электрофизиологических изменений во время индукции ОА может помочь понять влияние

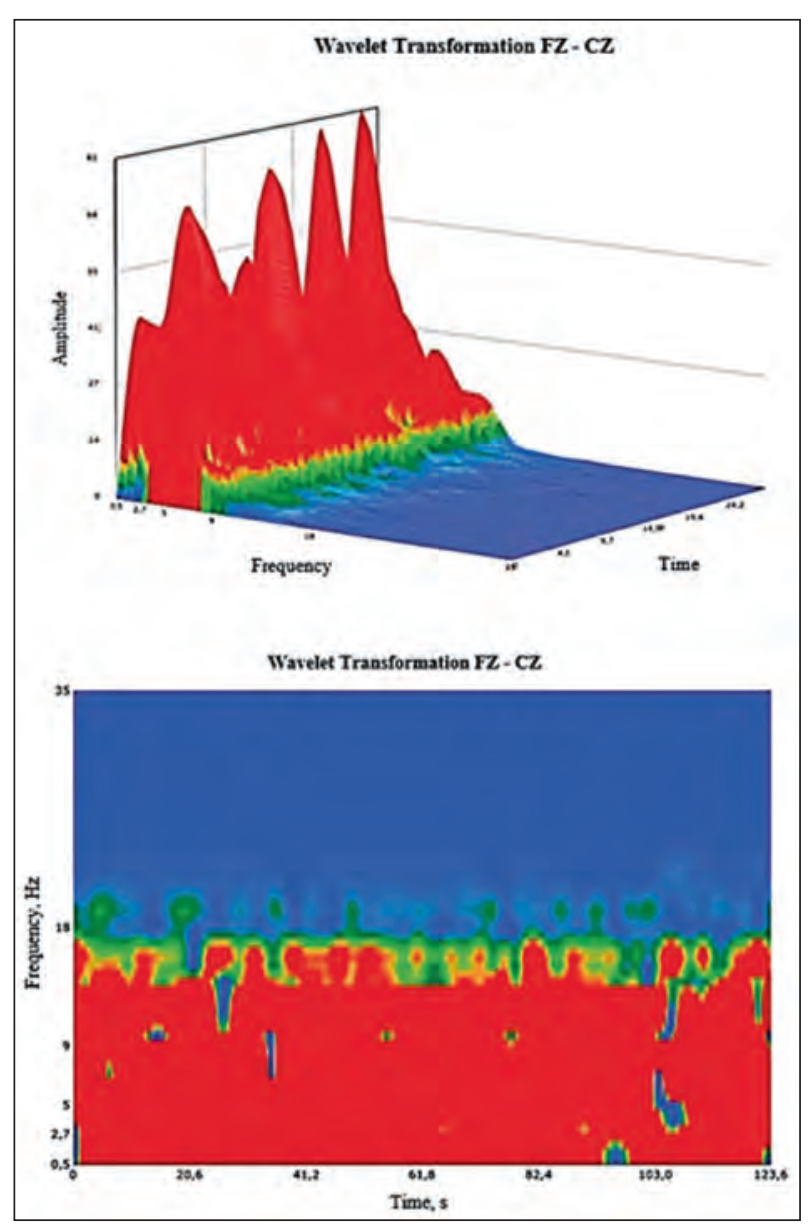

Рис. 5. Вейвлет-преобразование, показывающее трехмерное временно-частотное разложение для электрода $\mathrm{Fz}-\mathrm{Cz}$ и соответствующую спектрограмму, которая является дополнительным графическим представлением сигнала.

Fig. 5. Wavelet transformation showing a 3D time-frequency decomposition for the Fz-Cz electrode and the corresponding spectrogram. This represents a complementary graphical representation of the signal.

Note. We can see significant increases in amplitude for low theta and delta parts of the spectrum, which are indicators of deep anaesthesia.

Примечание. Можно видеть значительное увеличение амплитуды для низких тета- и дельта-частей спектра, которые являются индикаторами глубокой анестезии.

waves) may recover last after an episode of burstsuppression. Slow-wave activity manifests as global cortical waves $[30,31]$, so this result could point to impaired low-frequency functional connectivity after an episode of burst-suppression. This might be one of the reasons for the appearance of postoperative delirium, which has been correlated with prolonged intraoperative burstsuppression [11]. This hypothesis could be confirmed by studying burst-suppression using other brain imaging modalities, such as functional magnetic resonance imaging (fMRI) and magnetoencephalography (MEG). Differential rate of return from suppression for slower spectral components might be demonstrable by dif- 
общих анестетиков на структуры мозга и осветить механизмы изменения сознания во время ОА. Важную роль в этих явлениях играют таламокортикальная коммуникация и функциональная связь между участками коры, которые проявляются, в частности, в виде альфа-колебаний с поверхности головы [11, 27, 28]. По нашим данным, внутренние колебания, представляющие альфа-активность, в наибольшей степени предсказывали глобальные ПВП на ЭЭГ, что может отражать изменения в таламокортикальной связи во время подавления вспышки. Многообещающим клиническим маркером соответствующей глубины анестезии является насыщение медленно-волновой активности (англ. НМВА). Однако неизвестно, как ведет себя НМВА после возникновения феномена подавления вспышки. Наши результаты показывают, что низкочастотная активность (дельта- и медленные волны) может восстанавливаться после эпизода ПВП в последнюю очередь. Медленно-волновая активность проявляется в виде глобальных корковых волн [30, 31], поэтому данный результат может указывать на нарушение низкочастотной функциональной связи после эпизода ПВП. Это может быть одной из причин появления послеоперационного делирия, который коррелирует с длительным интраоперационным ПВП [11]. Данная гипотеза может быть подтверждена при изучении подавления вспышки с помощью других методов визуализации мозга, таких как функциональная магнитно-резонансная томография (фМРТ) и магнитоэнцефалография (МЭГ). Различная скорость восстановления более медленных спектральных компонентов после подавления подтверждается различной продолжительностью подавления у нейронных генераторов, лежащих в основе этих спектральных компонентов. Выявление точной локализации таких источников не входило в рамки нашего исследования, поскольку для этого потребовалось бы более высокое пространственное разрешение, чем имеющееся. Также было высказано предположение, что механизмы подавления вспышек незначительно отличаются в зависимости от конкретного анестетика, причем пропофол подавляет медленные ритмы сильнее, чем изофлуран [24]. Изучение спектрального содержания ЭЭГ при применении различных препаратов с помощью РЭМ может оказаться полезным для выяснения различий между механизмами, лежащими в основе их действия. Кроме того, имеются сообщения о локализованном появлении ПВП [32, 33]. Если различные ритмы вновь возникают на ЭЭГ после ПВП с разной скоростью, то это может проявиться, например, в виде изменений происхождения

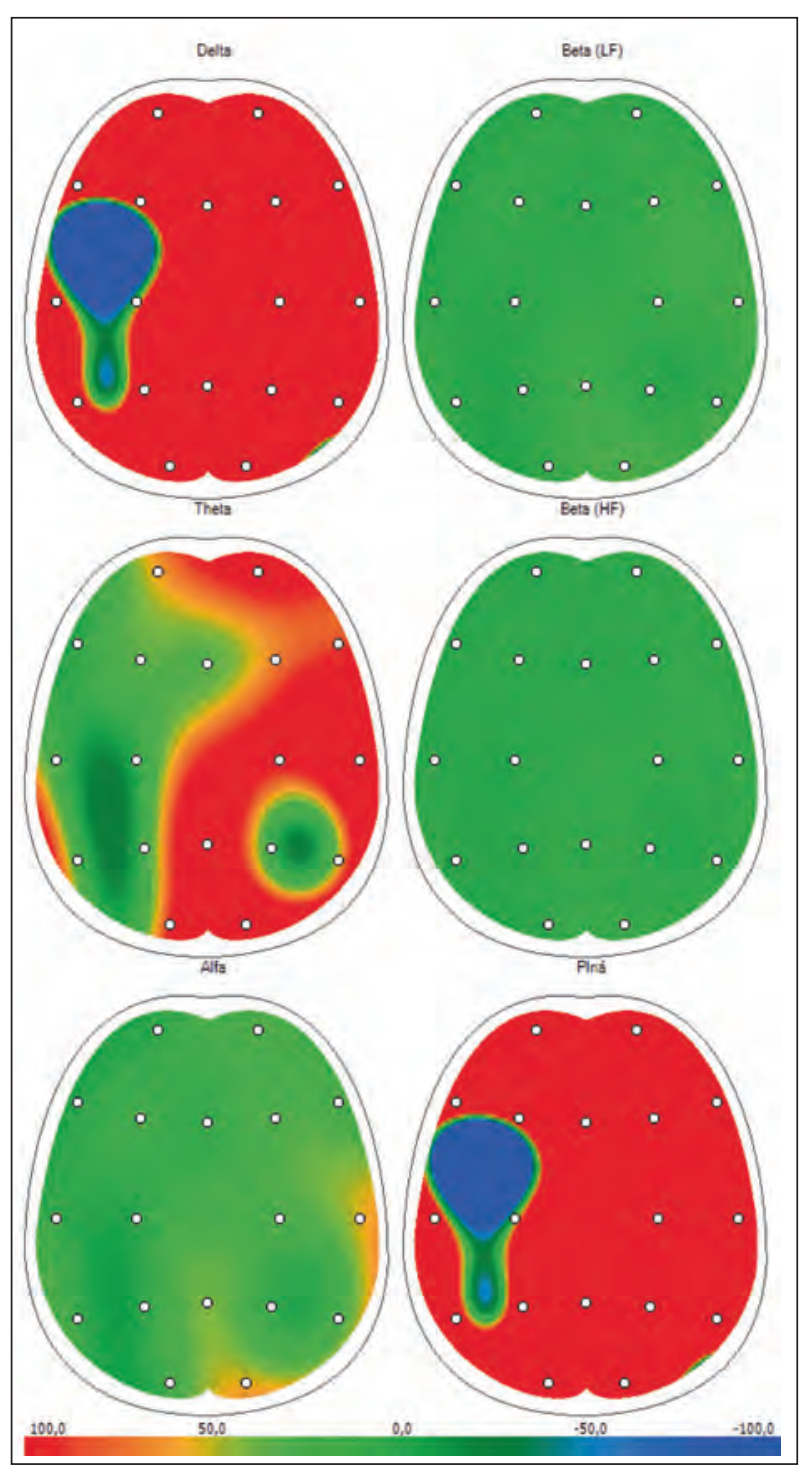

Рис. 6. Топографические карты ЭЭГ-активности во время общей анестезии.

Fig. 6. Topographical maps of EEG power during general anaesthesia.

ferent suppression durations for underlying neural generators of these spectral components. Such source localisation was beyond the scope of our study as it would require higher spatial resolution than that available. It has also been suggested burst-suppression mechanisms are subtly different between different anaesthetic agents, with propofol suppressing slower rhythms more than isoflurane [24]. Examining the spectral content of recordings from different agents using EMD might prove fruitful in elucidating the differences between the mechanisms underlying different substances. Furthermore, localised presence of burst-suppression has been reported in the literature $[32,33$ ]. If different rhythms return at different rates, this might show up as e. g. changes in the origins for individual slow waves. Multi-variate EMD is the subject of active re- 
отдельных медленных волн. Возможности применения многомерного РЭМ является предметом активных исследований [34-36]. Оно может использоваться в будущем для более подробного описания топографии подавления вспышек и их влияния на прогноз состояния пациента. Результатом внедрения результатов подобных исследований в клинику может стать создание более сложных и надежных клинических методов мониторинга активности мозга для использования в анестезиологии и интенсивной медицине.

\section{Заключение}

Применение РЭМ в нейрофизиологии. Данная публикация дает представление о методике разложения по эмпирическим модам (РЭМ) и ее применении для анализа ЭЭГ. РЭМ описывает сигнал ЭЭГ с помощью небольшого числа внутренних модовых функций, или внутренних колебаний (IMF). В отличие от методов, основанных на преобразовании Фурье, РЭМ не обладает какими-то изначально жестко фиксированными базовыми функциями, а также не предполагает линейность или стационарность сигнала. Наше исследование показало, что маскированное РЭМ позволяет разложить сигнал на физиологически значимые альфа-, дельта- и медленные колебательные компоненты без строгих предположений о частотных диапазонах, которые обычно применяются. РЭМ может описывать нелинейные формы осцилляций во время анестезии, что может способствовать дальнейшему выяснению мозговых генераторов этих сигналов с помощью неинвазивной записи, основываясь на ранних инвазивных исследованиях формы волны медленноволновой активности [37]. Несмотря на то, что РЭМ и соответствующее преобразование Гильберта-Хуанга (ННТ) уже применялись при анализе ЭЭГ, полученных во время анестезии [14, 38, 39], их использование не было широко распространено в нейрофизиологическом сообществе. В основном это связано с проблемой смешения мод, которая усложняет анализ и интерпретацию результатов РЭМ, а также с более длительной традицией использования методов, основанньх на преобразовании Фурье. В данной работе показали, что использование маскирующих сигналов дает ценное и рациональное разложение записи ЭЭГ, даже при наличии ПВП, возникающих при очень глубокой анестезии. РЭМ при анестезии применяется в основном для изучения энергетических спектров ННТ и анализа глобальной медленно-волновой активности, без описания феномена подавления вспышек, представленного в работе. Интерес к РЭМ среди неврологов search [34-36 ] and this method might be in the future applied to recordings like ours to even better describe the topographical properties of burst-suppression and its impact on patient prognosis. Clinical applications from such continued research could include an improved generation of more complex and robust clinical monitors of brain activity to be used in anaesthesiology and intensive medicine.

\section{Conclusion}

The use of EMD in Neurophysiology. This publication introduced the reader into the subject of Empirical Mode Decomposition (EMD) and its application to EEG analysis. EMD describes the EEG signal with a low number of Intrinsic Mode Functions (IMFs). In contrast with methods based on the Fourier transform, EMD does not assume the shape of its basis functions a priori, nor does it assume linearity or stationarity of the signal. Our study showed that masked EMD decomposed the signal into physiologically meaningful alpha, delta, and slow oscillatory components without strict assumptions about frequency bands normally applied. EMD can describe nonlinear shapes of oscillations during anaesthesia, which may further elucidate brain generators of these signals using non-invasive recordings, building on earlies invasive studies of waveform shape of slow-wave activity [37]. Even though EMD and the related Hilbert-Huang Transform (HHT) have been applied to anaesthetic recordings before [14, 38,39 ] the uptake in the neurophysiological community has been slow. This is mainly due to the problem of mode mixing, which complicates analysis and interpretation of EMD results, and because of a longer tradition of using Fourierbased methods. In this work we show that the use of masking signals produces a valuable and sensible decomposition of the EEG recording, even during the state of burst-suppression occurring in very deep anaesthesia. Existing applications of EMD to anaesthesia have focused on the HHT energy spectra and analysis of the entire recording of slow-wave activity, without describing burstsuppression like our analysis. Interest in EMD in the neuroscience and anaesthesia community is growing and this flexible method has the potential to improve clinical monitoring of neurophysiological signals and to further explain basic principles of functional mechanisms in the brain during anaesthesia.

Acknowledgements. This research was funded in whole, or in part, by the Wellcome Trust [Grant number 203139/Z/16/Z]. For the purpose of open access, the authors have applied a CC BY public copyright licence to any Author Accepted Manuscript version arising from this submission. The au- 
и анестезиологов растет, данная гибкая методика способна повысить качество клинического мониторинга нейрофизиологических сигналов и получить более глубокие представления об основных принципах функциональных механизмов головного мозга во время анестезии.

Благодарности. Это исследование полностью или частично финансировалось Wellcome Trust [номер гранта 203139/Z/16/Z]. В целях обеспечения открытого доступа авторы согласны с использованием любой версии данного документа и его производных согласно лицензии общественного авторского права СС. Авторы также благодарят Эндрю Куинна за обсуждение аспектов РЭМ и инструментария Python PЭM.

\section{Дополнительные} аспекты применения РЭМ

Применение РЭМ. Стандартный анализ частотно-временных данных в нейрофизиологии основан на преобразовании Фурье или вейвлет-преобразовании. Эти методики разлагают данные, представляющие собой сумму волн заранее определенной формы, и подразумевают линейность и стационарность сигналов. Однако известно, что сигналы, формируемые колебаниями активности нейронов, не обладают указанными свойствами [1-3]. В связи с этим, для полного понимания функциональной и клинической роли нейронных ритмов, необходимы методы с более гибким подходом к заранее определенным формам сигнала. Для решения подобной задачи было разработано несколько методов, использующих длинные сегменты данных или определенные точки колебаний $[4,5]$, при этом разложение по эмпирическим модам (РЭМ) можно отнести к новым перспективным методикам мгновенного анализа, которые могут количественно оценить большое число аспектов сигнала ЭЭГ [6-8]. Оценка деталей формы волны становится важным клиническим инструментом, поскольку ее несинусоидальное строение встречается при различных заболеваниях [9]. Известно, что колебания ЭЭГ при общей анестезии также носят несинусоидальный характер [10], однако важность данного факта пока объяснена не полностью. С учетом этого существует настоятельная необходимость внедрения в практику инструментов анализа, способных выявлять несинусоидальный характер волн. Последнее и достигается с помощью РЭМ.

Принципы работы РЭМ. При РЭМ происходит разложение данных временного ряда на небольшое количество внутренних модовых функций, или внутренних колебаний (IMF). Используемый метод радикально отличается thors also give thanks to Andrew Quinn for discussions about EMD and the Python EMD toolbox.

\section{Additional points on the use of EMD}

Why use EMD? Standard analysis of time-frequency data in neurophysiology is based on the Fourier or Wavelet Transform. These techniques decompose data as a sum of pre-defined waveforms and explicitly assume signals are linear and stationary. However, neural oscillations are known to violate these assumptions [1-3]. To fully understand the functional and clinical roles of neural rhythms, we therefore need techniques with weaker assumptions about the nature of our signal. Several methods have been developed to address this using long data segments or specific points in the oscillations [4, 5], but Empirical Mode Decomposition (EMD) is emerging as a suitable method with instantaneous resolution capable of quantifying more aspects of the EEG signal [6-8]. Capturing waveform details is emerging as an important clinical tool, as non-sinusoidal features have been linked to pathologies [9]. EEG oscillations under general anaesthesia are also known to be non-sinusoidal [10], but the importance of the non-sinusoidal shape is yet to be fully explained. There is therefore a pressing need to introduce analysis tools capable of capturing non-sinusoidality into the community, as we have done here with EMD.

How does EMD work? EMD decomposes time-series data into a small number of Intrinsic Mode Functions (IMFs). The method used is radically different to standard techniques such as the Short-time Fourier Transform or the Wavelet Transform. These have pre-defined basis functions and the decomposition tries to match their amplitudes to the data. In contrast, EMD is fully data-driven with fewer assumptions about the data. Specifically, decomposition is done through a process of sifting. First, upper and lower envelopes of the signal are defined by interpolating local maxima and minima. The local envelope mean is subtracted from the signal and the process is repeated until the resulting waveform converges sufficiently. This defines the first IMF, which is subtracted from the signal and the sifting process is repeated on the residue until only a linear trend remains $[11,12]$. Transient and intermittent oscillatory signals can lead to a mix of frequencies appearing in one IMF, which is known as mode mixing [13-15]. Injecting masking signals into the data has been used to address this problem, and this was the technique applied here $[6,14,16]$.

How does EMD compare to other techniques? The result of EMD is a small number of IMFs with well-defined instantaneous frequencies and amplitudes. This is in contrast to Wavelet/Fourier methods, which decompose the 
от стандартных методик, таких как кратковременное преобразование Фурье или вейвлетпреобразование. Последние имеют заранее определенные базисные функции, и при разложении пытаются подобрать свои амплитуды к полученным данным. В отличие от этого РЭМ полностью зависит от полученных данных и не использует фиксированные предположения об их характере. В частности, разложение осуществляется посредством просеивания. Сначала определяются верхняя и нижняя огибающие сигнала путем интерполяции локальных максимумов и минимумов. Среднее значение локальной огибающей вычитается из сигнала, и процесс повторяется до тех пор, пока результирующая форма сигнала не станет достаточно сходящейся. В результате получается IMF1, которая вычитается из сигнала, и процесс отсеивания повторяется на остатке, пока не останется только линейный тренд $[11,12]$. Транзиторные и прерывистые колебательные сигналы могут привести к смешению частот, появляющихся в одной IMF, называемому «смешением мод» [13-15]. Для решения этой проблемы можно использовать введение маскирующих сигналов в данные, и именно этот метод был применен в данном случае $[6,14,16]$.

Сравнение РЭМ с другими методиками. В результате применения методики РЭМ выявляется небольшое количество внутренних колебаний (IMF) с четко определенными мгно-

\section{Литература/References}

1. Sanders R.D., Tononi G., Laureys S., Sleigh J.W. Unresponsiveness $\neq$ Unconsciousness. Anesthesiology. 2012; 116 (4): 946-959. DOI: 10.1097/ALN.0b013e318249d0a7.

2. Ni Mhuircheartaigh R., Warnaby C., Rogers R., Jbabdi S., Tracey I. Slow-Wave Activity Saturation and Thalamocortical Isolation During Propofol Anesthesia in Humans. Sci Transl Med. 2013; 23; 5 (208): 208ra148. DOI: 10.1126/scitranslmed.3006007.

3. Warnaby C.E., Sleigh J.W., Hight D., Jbabdi S., Tracey I. Investigation of Slow-wave Activity Saturation during Surgical Anesthesia Reveals a Signature of Neural Inertia in Humans. Anesthesiology. 2017; 127 (4): 645-657. DOI: 10.1097/ALN.0000000000001759.

4. Marchant N., Sanders R., Sleigh J., Vanhaudenhuyse A., Bruno A.U., Brichant J.F., Steven Laureys S., Bonhomme V. How Electroencephalography Serves the Anesthesiologist. Clin EEG Neurosci. 2014; 45 (1): 22-32. DOI: 10.1177/1550059413509801.

5. Purdon P.L., Sampson A., Pavone K.J., Brown E.N. Clinical Electroencephalography for Anesthesiologists: Part I: Background and Basic Signatures. Anesthesiology. 2015; 123 (4): 937-960. DOI: 10.1097/ ALN.0000000000000841.

6. Marcuse L.V., Fields M.C., Jenna J. Y. The EEG in other neurologica and medical conditions and in status epilepticus. In: Rowan's Primer of EEG. 2nd ed. London: Elsevier, 2016: 157-173.

7. Gropper M. A. Miller's Anesthesia, 2-Volume Set E-Book [electronic resource], $9^{\text {th }}$ ed. 2019

8. Amzica F. What does burst suppression really mean? Epilepsy Behav 2015; 49: 234-237. DOI: 10.1016/j.yebeh.2015.06.012.

9. Hogan J., Sun H., Aboul Nour H., Jing J., Tabaeizadeh M., Shoukat M., Javed F., Kassa S., Edhi., Bordbar E., Gallagher J., Moura V. J., Ghanta M., Shao Y-P., Akeju O., Cole A.J., Rosenthal E.S., Zafar S., Westover M.B. Burst Suppression: Causes and Effects on Mortality in Critical Illnes. Neurocrit Care 2020; 33: 565-574. DOI: 10.1007/s12028-020-00932-4

10. Pontificia Universidad Catolica de Chile,. Study of the Association Between Burst Suppression During Anesthetic Induction With Propofol in Cardiac Surgery in Patients Over 65 Years of Age With Postoperative Delirium. Clinical trials.gov. Clinical trial registration NCT04713644, Mar. 2021. Accessed: Apr. 14, 2021. [Online]. Available: https: //clinicaltrials.gov/ct2/show/NCT04713644. signal into a large number of modes (potentially infinite) and analysis is done on pre-defined frequency bands. Large changes in the signal are captured by all methods, as was seen here with an increase in delta power in both the Wavelet spectrum and the relevant IMFs. However, the instantaneous resolution of EMD is of great advantage when analysing single cycle dynamics and describing non-sinusoidal shape features [6, 17]. EMD can also independently validate the use of specific frequency bands by showing the main features of interest in the signal automatically.

венными частотами и амплитудами. Это контрастирует с методом Фурье и вейвлет-методом, при которых происходит разложение сигнала на большое количество мод (потенциально бесконечное) и анализ проводят на заранее определенных частотных полосах. Большие изменения в сигнале улавливаются всеми методами, как это было видно в данном случае с увеличением дельта-мощности как в вейвлет-спектре, так и в соответствующих IMF. Однако мгновенное разрешение РЭМ имеет большое преимущество при анализе динамики одного цикла и описании особенностей несинусоидальной формы [6, 17]. РЭМ также может служить независимым методом валидации использования определенных частотных диапазонов, автоматически выявляя основные особенности сигнала, представляющие клинический интерес.

11. Soehle M., Dittmann A., Ellerkmann R.K., Baumgarten G., Putensen $C$., Guenther U. Intraoperative burst suppression is associated with postoperative delirium following cardiac surgery: a prospective, observational study. BMC Anesthesiol. 2015; 15 (61): 1-8. DOI: 10.1186/ s12871-015-0051-7.

12. Huang N.E., Shen Z., Long S., Wu M.C., Shih H.H., Zheng Q., Yen N. C., Tung C.C. Liu H.H. The empirical mode decomposition and the Hilbert spectrum for nonlinear and non-stationary time series analysis', Proc. R. Soc. Lond. Ser. Math. Phys. Eng. Sci. 1998; 454 (1971): 903995. DOI: 10.1098/rspa.1998.0193.

13. Huang N.E., Wu Z. A review on Hilbert-Huang transform: Method and its applications to geophysical studies. Rev. Geophys. 2008; 46 (2): 1-23. DOI: 10.1029/2007RG000228.

14. Kortelainen J., Vayrynen E. Assessing EEG slow wave activity during anesthesia using Hilbert-Huang Transform. Annu Int Conf IEEE Eng Med Biol Soc. 2015; 2015: 117-120. DOI: 10.1109/EMBC.2015.7318314.

15 Barbosh M., Singh P., Sadhu A. Empirical mode decomposition and its variants: a review with applications in structural health monitoring. Smart Mater. Struct. 2020; 29 (9): 093001. DOI: 10.1088/1361$665 X / a b a 539$.

16. Bueno-López M., Giraldo E., Molinas M., Fosso O.B. The Mode Mixing Problem and its Influence in the Neural Activity Reconstruction. IAENG International Journal of Computer Science. 2019; 46 (3): 11.

17. Yang Y., DengJ., Wu C. Analysis of Mode Mixing Phenomenon in the Empirical Mode Decomposition Method. In 2009 Second International Symposium on Information Science and Engineering, Shanghai, China; 2009: 553-556. DOI: 10.1109/ISISE.2009.19.

18. Wu Z., Huang N.E. Ensemble empirical mode decomposition: a noise-assisted data analysis method. Adv. Adapt. Data Anal. 2009; 01 (01): 1-41. DOI: 10.1142/S1793536909000047.

19 Deering R., Kaiser J.F The use of a masking signal to improve empirical mode decomposition. In: Proceedings. (ICASSP '05). IEEE International Conference on Acoustics, Speech, and Signal Processing. 2005; 4: iv/485-iv/488. DOI: 10.1109/ICASSP.2005.1416051.

20. Wang Y.H., Hu K., Lo M.T. Uniform Phase Empirical Mode Decomposition: An Optimal Hybridization of Masking Signal and Ensemble Approaches'. IEEE Access. 2018; 6: 34819-34833. DOI: 10.1109/ACCESS.2018.2847634.IEEE Access 2018; 6: 34819-34833. 
21. Gramfort A., Luessi M., Larson E., Engemann D.A., Strohmeier D. Brodbeck C.H., Goj R., Brooks T., Parkkonen L., Hämäläinen M. MEG and EEG data analysis with MNE-Python. Front Neurosci. 2013; 26 (7): 1-13. DOI: 10.3389/fnins.2013.00267.

22. Quinn A.J., Lopes dos Santos V., Dupret D., Nobre A.CH., Mark W. Woolrich M.W. EMD: Empirical Mode Decomposition and HilbertHuang Spectral Analyses in Python. J Open Source Softw. 2021; 6 (59): 1-8. DOI: 10.21105/joss.02977.

23. Quinn A.J, Lopes-dos-Santos V., Huang N., Liang W.K., Juan Ch.H., Yeh J-R., Nobre A.C., Dupret D., Woolrich M.W. Within-cycle instantaneous frequency profiles report oscillatory waveform dynamics. bioRxiv. 2021.04.12.439547. DOI: 10.1101/2021.04.12.439547.

24. Kenny J.D., Westover M.B., Ching S., Brown E.N., Solt K. Propofol and sevoflurane induce distinct burst suppression patterns in rats. Front. Syst. Neurosci. 2014; 8 (237): 1-13. DOI: 10.3389/fnsys.2014.00237.

25. Vijn P.C., Sneyd J.R. I.v. anaesthesia and EEG burst suppression in rats: bolus injections and closed-loop infusions. Br. J. Anaesth. 1998; 81 (3): 415-421. DOI: 10.1093/bja/81.3.415.

26. Freye E., Levy J.V.Cerebral Monitoring in the Operating Room and the Intensive Care Unit: An Introductory for the Clinician and a Guide for the Novice Wanting to Open a Window to the Brain. J. Clin. Monit. Comput. 2005; 19 (1): 1-76. DOI: 10.1007/s10877-005-0712-Z.

27. Hesse S., Kreuzer M., Hight D., Gaskell A., Devari P., Singh D., Taylor N.B., Whalin M.K., Lee S., Sleigh J.W., Garcia P.S.Association of electroencephalogram trajectories during emergence from anaesthesia with delirium in the postanaesthesia care unit: an early sign of postoperative complications'. Br. J. Anaesth. 2019; 122 (5): 622-634. doi 10.1016/j.bja.2018.09.016.

28. Hight D., L. J. Voss L.J., Garcia P.S., J. Sleigh J.W. Changes in Alpha Frequency and Power of the Electroencephalogram during VolatileBased General Anesthesia. Front. Syst. Neurosci. 2017; 11 (36): DOI: 10.1016/j.bja.2018.09.016.10 doi: 10.3389/fnsys.2017.00036.

29. Sleigh J., Pullon R.M., Vlisides P.E., Warnaby C.E. Electroencephalographic slow wave dynamics and loss of behavioural responsiveness induced by ketamine in human volunteers. Br. J. Anaesth. 2019; 123 (5): 592-600. DOI: 10.1016/j.bja.2019.07.021.

30. Massimini M., Huber R., Ferrarelli F, Hill S., Giulio T. The Sleep Slow Oscillation as a Traveling Wave. J. Neurosci. 2004; 24 (31): 6862-6870. DOI: 10.1523/JNEUROSCI.1318-04.2004.

31. Murphy M., Bruno M-A., Riedner B.A., Boveroux P., Noirhomme Q., Landsness E., Brichant J-F., Phillips Ch., Massimini M., Laureys S., Tononi G., Boly M. Propofol Anesthesia and Sleep: A High-Density EEG Study. Sleep. 2011; 34 (3): 283-291A: DOI: 10.1093/sleep/ 34.3.283.

32. Lewis L.D., Ching Sh., Weiner V.S, Peterfreund R.A., Eskandar E.N., Cash S.S., Brown E.N., Purdon P.L. Local cortical dynamics of burst suppression in the anaesthetized brain. Brain. 2013; 136 (9) $2727-$ 2737. DOI: $10.1093 /$ brain/awt174.

33. Ming Q., Liou J-Y., Yang F, Li J., Chu Ch., Zhou Q., Wu D., Xu S., Luo P. Liang J., Li D., Pryor K.O., Lin W., Schwartz T., Ma H. Isoflurane-Induced Burst Suppression Is a Thalamus-Modulated, Focal-Onset Rhythm With Persistent Local Asynchrony and Variable Propagation Patterns in Rats. Front. Syst. Neurosci. 2021; 14: 1-11. DOI: $10.3389 /$ fnsys.2020.599781.

34. Lang X., Zheng Q., Zhang Z., Lu S., Xie L., Horch A., Su H. Fast Multivariate Empirical Mode Decomposition. IEEE Access PP; 2018; 99 : 1-18. DOI: 10.1109/ACCESS.2018.2877150.

35. Rehman N., Mandic D.P. Multivariate empirical mode decomposition. Proc. R. Soc. Math. Phys. Eng. Sci. 2010; 466 (2117): 12911302.DOI: 10.1098/rspa.2009.0502.

36. Wu Z., Feng J., Qiao F., Tan Z.-M. Fast multidimensional ensemble empirical mode decomposition for the analysis of big spatio-temporal datasets. Philos. Trans. R. Soc. Math. Phys. Eng. Sci. 2016; 374 (2065): 20150197. DOI: 10.1098/rsta.2015.0197.

37. Amzica F. Steriade M. Electrophysiological correlates of sleep delta waves. Electroencephalogr. Clin. Neurophysiol. 1998; 107 (2): 69-83. DOI: 10.1016/S0013-4694 (98)00051-0.
38. Chen S-J., Peng Ch-J., Chen Y-Ch., Hwang Y-R., Lai Y-S., Fan S-Z., Jen $K$ - $K$. Comparison of FFT and marginal spectra of EEG using empirical mode decomposition to monitor anesthesia. Comput. Methods Programs Biomed. 2016; 137: 77-85. DOI: 10.1016/j.cmpb.2016.08.024.

39. Li Ch., Li D., Liang Z., Voss L.J., Sleigh J.W. Analysis of depth of anesthesia with Hilbert-Huang spectral entropy. Clin. Neurophysiol.2008; 119 (11): 2465-2475. DOI: 10.1016/j.clinph.2008.08.006.

\section{Дополнительные источники/Supplemets}

1. Cole S. R., Voytek B. Brain Oscillations and the Importance of Waveform Shape. Trends Cogn. Sci. 2017; 21 (2): 137-149. DOI: 10.1016/ j.tics.2016.12.008.

2. van Ede F, Quinn A.J., Woolrich M.W., Nobre A.C. Neural Oscillations Sustained Rhythms or Transient Burst-Events? Trends Neurosci. 2018; 41 (7): 415-417. DOI: 10.1016/j.tins.2018.04.004.

3. Vidaurre D., Quinn A.J.,Baker A.P, Dupret D., Tejero-Cantero A.,Woolrich M.W. Spectrally resolved fast transient brain states in electrophysiological data. NeuroImage. 2016; 126: 81-95. DOI: 10.1016/j.neuroimage.2015.11.047.

5. Bartz S., Avarvand F.S., Leicht G., Nolte G. Analyzing the waveshape of brain oscillations with bicoherence. NeuroImage. 2019; 188: 145-160. DOI: 10.1016/j.neuroimage.2018.11.045.

6. Quinn A.J. Within-cycle instantaneous frequency profiles report oscillatory waveform dynamics. bioRxiv, 2012: 2021.04.12.439547. DOI: 10.1101/2021.04.12.439547.

7. Soler A., Muñoz-Gutiérrez P.A., Bueno-López M., Giraldo E., Molinas $M$. Low-Density EEG for Neural Activity Reconstruction Using Multivariate Empirical Mode Decomposition. Front. Neurosci; 2020: 14 DOI: $10.3389 /$ fnins.2020.00175.

8. Kortelainen J., Väyrynen E. Assessing EEG slow wave activity during anesthesia using Hilbert-Huang Transform. in 2015 37th Annual International Conference of the IEEE Engineering in Medicine and Biology Society (EMBC). 2015: 117-120. doi: 10.1109/EMBC.2015.7318314.

9. Cole S.R., van der Meij R., Peterson E.J., de Hemptinne C., Starr P.A., Voytek B. Nonsinusoidal Beta Oscillations Reflect Cortical Pathophysiology in Parkinson's Disease. J. Neurosci. 2017; 37 (18): 4830-4840. DOI: 10.1523/JNEUROSCI.2208-16.2017.

10. Amzica F, Steriade M. 'Electrophysiological correlates of sleep delta waves', Electroencephalogr. Clin. Neurophysiol. 1998; 107 (2): 69-83. DOI: 10.1016/S0013-4694 (98)00051-0.

11. Huang N.E., Shen Zh., Long S.R., Wu M.L.C. The empirical mode decomposition and the Hilbert spectrum for nonlinear and non-stationary time series analysis. Lond. Ser. Math. Phys. Eng. Sci. 1998; 454 (1971): 903-995. DOI: 10.1098/rspa.1998.0193.

12. Wang Y.-H, Hu K., Lo M.-T. Uniform Phase Empirical Mode Decomposition: An Optimal Hybridization of Masking Signal and Ensemble Approaches', IEEE Access. 2018; 6: 34819-34833. DOI: 10.1109/ACCESS.2018.2847634.

13. Yang Y., Deng J., Wu C. Analysis of Mode Mixing Phenomenon in the Empirical Mode Decomposition Method', in 2009 Second International Symposium on Information Science and Engineering, Shanghai, China. 2009: 553-556. DOI: 10.1109/ISISE.2009.19.

14. Deering R., Kaiser J.F. The use of a masking signal to improve empirical mode decomposition', in Proceedings. (ICASSP '05). IEEE International Conference on Acoustics, Speech, and Signal Processing. 2005; 4: iv/485-iv/488. DOI: 10.1109/ICASSP.2005.1416051.

15. $W u$ Z., Huang N.E. Ensemble empirical mode decomposition: a noise-assisted data analysis method. Adv. Adapt. Data Anal. 2009: 01 (01): 1-41. DOI: 10.1142/S1793536909000047.

16. Fabus M.S., Quinn A.J., Warnaby C.E., Woolrich M.W. Automatic decomposition of electrophysiological data into distinct non-sinusoidal oscillatory modes. bioRxiv, 2021: 2021.07.06.451245. DOI: 10.1101/2021.07.06.451245

17. Lo M.-T., Novak V., Peng C.-K., Liu Y., Hu K. Nonlinear phase interaction between nonstationary signals: A comparison study of methods based on Hilbert-Huang and Fourier transforms. Phys. Rev. E Stat Nonlin. Soft Matter Phys. 2009; 79 (6 Pt 1): 061924 DOI: 10.1103/PhysRevE.79.061924.

Поступила/Received 2021.05.05 